Article

\title{
New Analytical Tools for Unmasking Frauds in Raw Milk-Based Dairy Products: Assessment, Validation and Application to Fiore Sardo PDO Cheese of a RP-HPLC Method for the Evaluation of the $\alpha-1-F u c o s i d a s e$ Activity
}

\author{
Alessio Silvio Dedola ${ }^{1}$, Luca Piras ${ }^{2}$, Margherita Addis ${ }^{1}\left({ }^{\circ}\right.$, Antonio Pirisi $\left.{ }^{1}{ }^{(}\right)$, \\ Giovanni Piredda ${ }^{1}$, Andrea Mara ${ }^{2}$ and Gavino Sanna ${ }^{2, *(\mathbb{D})}$ \\ 1 Agris Sardegna, Servizio Ricerca Prodotti di Origine Animale, Loc. Bonassai, 07044 Olmedo (SS), Italy; \\ adedola@agrisricerca.it (A.S.D.); maddis@agrisricerca.it (M.A.); apirisi@agrisricerca.it (A.P.); \\ gpiredda@agrisricerca.it (G.P.) \\ 2 Dipartimento di Chimica e Farmacia, Università degli Studi di Sassari, Via Vienna 2, 07100 Sassari (SS), Italy; \\ piras-luca@libero.it (L.P.); a.mara@studenti.uniss.it (A.M.) \\ * Correspondence: sanna@uniss.it; Tel.: +39-079-229500
}

Received: 11 June 2020; Accepted: 7 July 2020; Published: 9 July 2020

check for updates

\begin{abstract}
The activity of $\alpha$-l-fucosidase (FSC) has been measured for the first time in Fiore Sardo PDO (Protected Designation of Origin) raw milk cheese. To do this, a RP-HPLC method has been developed, validated and tested on a reliable sampling of cheese experimentally produced in laboratory batches. Three experimental factors have been considered in this work: the thermal treatment undergone by the milk, the lactation period and the ripening time of cheese. Results obtained have evidenced: (i) a meaningful reduction in the activity of FSC from cheeses produced using raw milk to those obtained by thermized milk; (ii) an increase in the activity of FSC during the first months of lactation period (from December to February), followed by a substantial constancy in the central and final months of lactation (from February to May); (iii) the enzyme activity is independent of the ripening time. This method might be useful in revealing frauds related to the use of mild thermal treatments of the milk when this is not allowed as for Fiore Sardo PDO cheese but also for several PDO cheeses for which the specifications establish that raw milk only must be used for their production.
\end{abstract}

Keywords: sheep milk; raw milk; Fiore Sardo PDO; thermization; $\alpha$-l-fucosidase; RP-HPLC

\section{Introduction}

Fiore Sardo PDO (Protected Designation of Origin) sheep milk cheese is one of the most ancient and traditional cheeses from Sardinia, Italy. It is an uncooked cheese which, as required by the PDO specification [1], must be produced exclusively by raw whole milk from Sarda sheep. The use of raw milk is essential for Fiore Sardo PDO cheese (henceforward simply called "Fiore Sardo") to preserve a strong link with its production area and the sensory characteristics deriving from the pastures. Consumer demand for unpasteurized milk cheeses is constantly increasing thanks to their more intense flavor and aroma than those of thermized or pasteurized milk cheeses. On the other hand, in order to ensure the highest food safety requirements, products based on raw milk require a combination of several factors including the rate and extent of curd acidification in the first hours of the production, together with a quite deep salting and a long ripening time.

Thermal treatment is the most common method to increase the safety and shelf life of milk and dairy products. However, this practice could have negative effects on their nutritional and sensory 
properties, and it is one of the most common causes of non-compliance with the PDO specification of Fiore Sardo, which entails damage to its reputation.

In order to verify compliance with the product specification, the presence of highly thermolabile endogenous enzymes in cheese could provide proof of the absence of a specific heat treatment applied to the cheese milk. In Europe, the transposition of the Council EU Directive 92/46 EEC [2] establishes the health rules for the production and marketing of raw milk, heat-treated milk and milk for the manufacture of dairy products for human nutrition. In this context, the absence of any activity of alkaline phosphatase (ALP, EC 3.1.3.1) [3,4] and lactoperoxidase (EC 1.11.1.7) [5] are considered as discriminating parameters to ascertain the pasteurization and the high pasteurization of milk, respectively. On the other hand, no EU directive has been released with the aim to ascertain the absence of heat treatments in milk or in raw milk-based dairy products. This is reflected in the scarce attention addressed towards the development, validation and application of analytical methods able to achieve this result in a reliable way.

In this context, the pasteurization of cow milk [6-12] has been the system most frequently studied, whereas less common are the contributions regarding non cow-milk and related dairy products [12-18] and/or to mild thermal treatments (e.g., thermization) [17-21].

To the best of our knowledge, there is no analytical method able in a simple way to discriminate cheeses produced from raw and thermized milk (i.e., milk heated to $57-68{ }^{\circ} \mathrm{C}$ for $15 \mathrm{~s}$ ). One of the most important thermolabile enzymes in milk is the $\alpha$-1-fucosidase (FSC, EC 3.2.1.51). This lysosomal enzyme has been determined in ovine [16], bovine [21,22] and human [23]) milk. In the literature, there is evidence of the thermal inactivation of FSC in bovine $[19,21]$ and sheep milk [18] which take place below the typical temperature range used for thermization. Our research group is active in the assessment and validation of original methods for the determination of analytes of specific interest in Fiore Sardo [24-27]. Since the development of a specific analytical method able to detect, with a low limit of detection and high accuracy, the activity of FSC in raw milk cheeses is unprecedented in the literature, the principal aims of the present study are to develop and validate an analytical procedure devoted to measuring the activity of the FSC in cheese, and to test this procedure with Fiore Sardo samples made from raw or thermized sheep milk, respectively.

\section{Materials and Methods}

\subsection{Cheese Production and Sampling}

The cheesemaking trials were performed, as already reported by Caboni et al. 2019 [27], in the experimental cheese factory of Agris Sardegna, using whole bulk Sarda sheep's milk. Each trial was repeated four times along the lactation period (i.e., in December 2016, in February 2017, in April 2017, and in May 2017). In every cheesemaking trial, $120 \mathrm{~kg}$ of sheep raw milk was divided into two aliquots: the first $60 \mathrm{~kg}$ aliquot was thermized (TM) and then processed into cheese, the second $60 \mathrm{~kg}$ aliquot was processed as raw milk (RM). Thermal treatment was performed by using an infrared tubular exchanger (model Stoutz-Actinator, Actini Group, France) in which milk was heated at $68^{\circ} \mathrm{C}$ for $30 \mathrm{~s}$ and quickly cooled down to $38^{\circ} \mathrm{C}$.

Fiore Sardo cheese type was manufactured for analytical purposes. In order to eliminate any possible differences due to the used cheese vat, two different vats have been alternatively used in the cheesemaking of the RM and TM, respectively, whereas the dairyman was always the same.

During each cheesemaking trial, a freeze-dried mixed starter culture was added to both RM and TM milk (CHOOZIT MA11 LYO, Danisco) at 7 Direct Culture Unit (DCU) $100 \mathrm{dm}^{-3}$ of milk. A soluble lamb rennet paste (1:10000 strength rennet as Soxhlet unit, Caglificio Manca, Thiesi, Italy) was used in an amount that allowed the coagulation of milk in $12 \mathrm{~min}$. After a duration of 2 times the clotting time, the coagulum was cut into small granules $(2-4 \mathrm{~mm})$ and filled into molds. Cheese loaves, (6 raw milk cheeses (RC) and 6 thermized milk cheeses (TC)) weighing from 1.5 to $1.7 \mathrm{~kg}$ each, were obtained and sweated at $34-36^{\circ} \mathrm{C}$ for $3-4 \mathrm{~h}$, until they reached $\mathrm{pH}$ 5.2-5.4. Cheeses were then salted in brine 
$\left(22-24 \%\right.$ of $\mathrm{NaCl}$ ) for $12 \mathrm{~h} \mathrm{~kg}^{-1}$ cheese and finally, ripened at $10-12{ }^{\circ} \mathrm{C}$ and relative humidity between $80 \%$ and $85 \%$ for up to 180 days.

A total of 24 RC and 24 TC samples were obtained. Twelve RC and 12 TC were sampled for analysis at 105 and 180 days of ripening, respectively.

\subsection{Milk and Cheese Composition}

Gross composition of the milk was determined for $\mathrm{pH}$, fat, proteins, caseins, lactose and dry matter (DM) content, whereas the gross compositions of the cheeses after 105 and 180 days of ripening were determined by measuring $\mathrm{pH}$, moisture, proteins, fat and $\mathrm{NaCl}$ content. Tables 1 and 2 show the average gross composition of both milk and cheeses in due course extensively reported by Caboni et al. 2019 [27], and here summarized as means values and ranges of variation.

Table 1. Gross composition of raw and thermized sheep milk samples.

\begin{tabular}{ccccc}
\hline & \multicolumn{3}{c}{ Treatment of the Milk } \\
\cline { 2 - 5 } & \multicolumn{2}{c}{ Raw Milk } & \multicolumn{2}{c}{ Thermized Milk } \\
\hline Chemical Parameters & Mean \pm sd & Range & Mean \pm sd & Range \\
\hline pH & $6.66 \pm 0.04$ & $6.61-6.70$ & $6.67 \pm 0.03$ & $6.63-6.69$ \\
Dry matter (\%) & $15.5 \pm 0.4$ & $15.1-15.9$ & $15.5 \pm 0.3$ & $15.2-15.9$ \\
Fat (\%) & $5.0 \pm 0.3$ & $4.5-5.2$ & $5.0 \pm 0.4$ & $4.5-5.3$ \\
Proteins (\%) & $5.2 \pm 0.2$ & $4.9-5.3$ & $5.2 \pm 0.2$ & $5.0-5.3$ \\
Casein (\%) & $3.9 \pm 0.2$ & $3.7-4.1$ & $3.9 \pm 0.1$ & $3.7-4.1$ \\
Lactose (\%) & $4.6 \pm 0.1$ & $4.6-4.7$ & $4.6 \pm 0.1$ & $4.6-4.7$ \\
\hline
\end{tabular}

sd, standard deviation.

Table 2. Gross composition of raw and thermized cheeses after 105 and 180 days of ripening, respectively.

\begin{tabular}{cccccccccc}
\hline \multicolumn{1}{c}{ Ripening Time } & \multicolumn{3}{c}{ 105 Days } & \multicolumn{3}{c}{ 180 Days } \\
\hline Treatment of the Milk & \multicolumn{2}{c}{ Raw Milk } & \multicolumn{2}{c}{ Thermized Milk } & \multicolumn{2}{c}{ Raw Milk } & Thermized Milk \\
\hline Chemical Parameters & Mean \pm sd & Range & Mean \pm sd & Range & Mean \pm sd & Range & Mean \pm sd & Range \\
\hline pH & $5.1 \pm 0.1$ & $5.0-5.2$ & $5.1 \pm 0.1$ & $5.0-5.2$ & $5.1 \pm 0.2$ & $4.9-5.2$ & $5.1 \pm 0.1$ & $4.9-5.3$ \\
Moisture (\%) & $31 \pm 2$ & $29-33$ & $31 \pm 2$ & $29-33$ & $26 \pm 1$ & $24-27$ & $27 \pm 1$ & $26-28$ \\
Fat (\%) & $33 \pm 2$ & $30-36$ & $33.3 \pm 2.5$ & $30.5-36.0$ & $36 \pm 2$ & $34-39$ & $35 \pm 3$ & $33-38$ \\
Protein (\%) & $29 \pm 2$ & $26-30$ & $29 \pm 2$ & $26-30$ & $31 \pm 2$ & $29-32$ & $31 \pm 1$ & $29-32$ \\
NaCl (\%) & $1.8 \pm 0.1$ & $1.7-1.9$ & $1.9 \pm 0.2$ & $1.8-2.2$ & $1.9 \pm 0.1$ & $1.8-2.0$ & $2.0 \pm 0.2$ & $1.8-2.2$ \\
\hline & & \multicolumn{3}{c}{ sd, standard deviation. } & &
\end{tabular}

\subsection{Method Assessment}

\subsubsection{Reagents}

Ultrapure (type 1) water (specific resistance $\geq 18 \mathrm{M} \Omega$ ) was used for all needs. Hydrochloric acid (ACS, 37\%), acetic acid (ACS, 99\%), ethanol (ACS reagent) and acetonitrile (HPLC grade) were from VWR International (Milan, Italy). $p$-nitrophenol ( $p$ NP), $p$-nitrophenyl- $\alpha$-l-fucopyranoside ( $p$ NPFP), sodium acetate $\left(0.5 \mathrm{~mol} \mathrm{dm}^{-3}\right.$ in water, $\left.\mathrm{pH}=5.5\right)$ and tris (hydroxymethyl)aminomethane (TRIS) $\left(1.0 \mathrm{~mol} \mathrm{dm}^{-3}\right.$ in water, $\left.\mathrm{pH}=10.0\right)$ were from Sigma-Aldrich (Milan, Italy). Acetone and $n$-hexane (both ACS, from VWR International, Milan, Italy) were used for carefully washing the glassware prior to its use. All HPLC solvents were previously filtered through a $0.45-\mu \mathrm{m}$ membrane (Millipore, Bedford, MA, USA) to remove any impurities.

\subsubsection{Instrumentation, Literature Methods and Chromatographic Conditions}

Fat, proteins, caseins and lactose contents were measured in milk using a Combifoss FT+ FTIR analyzer (Foss, Hillerød, Denmark), whereas $\mathrm{pH}$ was measured in milk and cheese samples using a pH meter model Basic 20+ (Crison Instruments S.A., Alella, Spain). An automatic titrator model 
DL55 (Mettler-Toledo $\mathrm{GmbH}$, Schwerzenbach, Switzerland) was used to measure $\mathrm{NaCl}$ content in cheeses. A liquid chromatography Agilent Series 1100 (Agilent Technologies, Palo Alto, CA, USA) equipped with a Guard-RP, HI-5RP-10C5/K pre-column (Agilent Technologies) a Hyperclone column, $4.6 \mathrm{~mm}$ i.d. $\times 150 \mathrm{~mm}, 5-\mu \mathrm{m}$ particle size (Phenomenex, Milan, Italy) and a UV/VIS detector Model 1260 Infinity G1314B 1260VWD VL (Agilent Technologies, Palo Alto, CA, USA) was used for all the HPLC analyses. The temperature of the column was kept at $25^{\circ} \mathrm{C}$, the flux of the mobile phase was set at $1 \mathrm{~cm}^{3} \mathrm{~min}^{-1}$ and the UV/VIS detector was set to $315 \mathrm{~nm}$. Chromatographic data were processed using the software Open Lab (Agilent Technologies, Palo Alto, CA, USA). Finally, the determination of all parameters of milk gross composition and cheeses have been accomplished by the International Organization for Standardization ISO [28-31] or literature-based methods [32].

\subsubsection{Sampling Procedure of the Cheese}

Cheese samples were obtained taking two opposed slices from each loaf (300 g in total), which were then finely grinded by an electric grate and finally homogeneously mixed.

\subsubsection{Extraction Procedure}

Since FSC is characterized by a rather good solubility in water [19], its extraction by the matrix is quite easy. Hence, the homogenization of $10 \mathrm{~g}$ of grated cheese in $20 \mathrm{~cm}^{3}$ of ultrapure water was accomplished by means of an ultraturrax ( $1 \mathrm{~min}$ at 16,000 rpm). The mixture was then diluted up to $50 \mathrm{~cm}^{3}$ with water, filtered twice on Whatman 42 filter paper (VWR International, Milan, Italy). An aliquot of the extract was used for the enzymatic hydrolysis of $p$ NPFP.

\subsubsection{Enzymatic Hydrolysis of $p$ NPFP}

The analytical method was developed adapting the procedures previously described by this research group $[17,21]$ to the cheese matrix. Hence, $0.100 \mathrm{~cm}^{3}$ of filtered cheese extract was transferred into a vial and $0.100 \mathrm{~cm}^{3}$ of substrate-buffer solution (a buffer solution $0.5 \mathrm{~mol} \mathrm{dm}^{-3}$ each for $\mathrm{CH}_{3} \mathrm{COONa}$ and $\mathrm{CH}_{3} \mathrm{COOH}$, containing $5 \mathrm{mmol} \mathrm{dm}^{-3}$ of $p \mathrm{NPFP}$ ) was added. The solution was gently stirred and incubated for $4 \mathrm{~h}$ at $37^{\circ} \mathrm{C}$. Subsequently, $3.5 \mathrm{~cm}^{3}$ of ethanol and $1.5 \mathrm{~cm}^{3}$ of $1 \mathrm{~mol} \mathrm{dm}{ }^{-3}$ TRIS Base solution buffered at $\mathrm{pH}=10$ were added and vortexed. The mixture was then centrifuged at $2700 \times g$ for $5 \mathrm{~min}$ at room temperature. An amount of $0.050 \mathrm{~cm}^{3}$ of the supernatant solution, vortexed and filtered on a 0.2- $\mu \mathrm{m}$ Whatman FP 30 filter (Phenomenex, Bologna, Italy) was analyzed by HPLC.

\subsubsection{HPLC Analysis}

The gradient program of the HPLC method is summarized in Table 3.

Table 3. Gradient program used in the HPLC analysis.

\begin{tabular}{|c|c|c|}
\hline Time (min) & $\begin{array}{c}\text { Solvent } \mathrm{A} \\
\text { 99:1 (v/v) } \mathrm{CH}_{3} \mathrm{CN}: \mathrm{CH}_{3} \mathrm{COOH}(\%)\end{array}$ & $\begin{array}{c}\text { Solvent B } \\
\text { 99:1 (v/v) } \mathrm{H}_{2} \mathrm{O}: \mathrm{CH}_{3} \mathrm{COOH} \mathrm{( \% )}\end{array}$ \\
\hline 0 & 10 & 90 \\
\hline 5 & 25 & 75 \\
\hline 10 & 30 & 70 \\
\hline 20 & 100 & 0 \\
\hline 25 & 10 & 90 \\
\hline
\end{tabular}

Each HPLC run was accomplished in $25 \mathrm{~min}$. A typical chromatogram of a real sample of Fiore Sardo PDO is shown in Figure 1. 


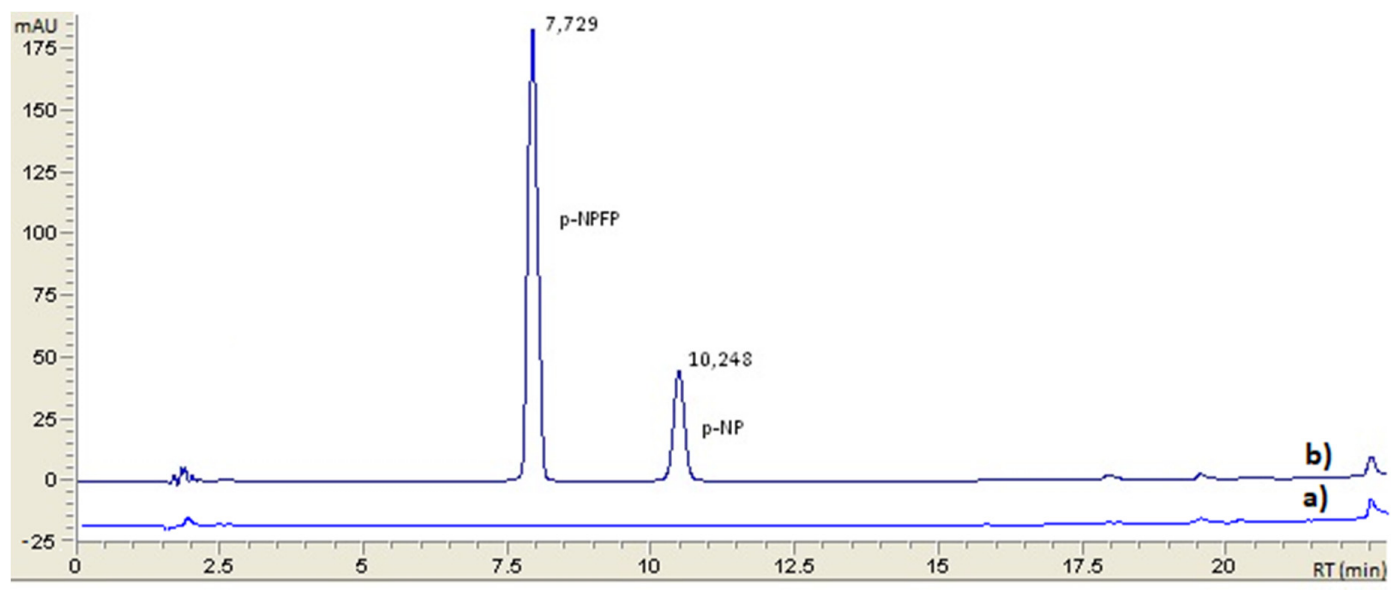

Figure 1. RP-HPLC evaluation of $\alpha$-l-fucosidase activity in Fiore Sardo PDO (protected designation or origin) sheep's cheese. (a) Chromatogram of the blank; (b) chromatogram of a real sample (RC, February, after 105 days of ripening). Peak 1, p-nitrophenyl- $\alpha$-l-fucopyranoside, $p$-NPFP; peak 2, p-nitrophenol, $p$-NP.

\subsubsection{Quantification}

Quantification was accomplished by external calibration. Standard solutions were prepared with the same procedure described in the Enzymatic hydrolysis of $p$ NPFP section, using $0.100 \mathrm{~cm}^{3}$ filtered cheese extracts thermally inactivated $\left(100{ }^{\circ} \mathrm{C}\right.$ for $\left.5 \mathrm{~min}\right)$ and-in place of the $0.100 \mathrm{~cm}^{3}$ of the substrate-buffer solution $-0.100 \mathrm{~cm}^{3}$ of buffered solutions at increasing concentrations of $p$ NP. The blank was a solution containing all the above compounds with the exception of $p$ NP. The concentration of $p \mathrm{NP}$, expressed in $\mathrm{mmol} \mathrm{dm^{-3 }}$ was obtained by linear interpolation on the calibration plot. The concentration of $p \mathrm{NP}$ is hence converted into units of FSC activity ( $\mathrm{U}$ per $\mathrm{cm}^{3}$ of cheese extract per hour, Equation (1); U per hour per g of cheese, Equation (2); U per hour per g dry matter (DM) of cheese, Equation (3) according the following relationships:

$$
\begin{gathered}
\mathrm{U} \cdot \mathrm{h}^{-1} \cdot \mathrm{cm}^{-3}=[p \mathrm{NP}] \times 500 \\
\mathrm{U} \cdot \mathrm{h}^{-1} \cdot \mathrm{g}^{-1} \text { of cheese }=\frac{\mathrm{U} \mathrm{cm}{ }^{-3} \mathrm{~h}^{-1} \times 50 \mathrm{~cm}^{3}}{\mathrm{~g} \text { cheese }} \\
\mathrm{U} \cdot \mathrm{h}^{-1} \cdot \mathrm{g}_{\mathrm{DM}}{ }^{-1} \frac{\mathrm{U} \mathrm{cm}{ }^{-3} \mathrm{~h}^{-1} \times 50 \mathrm{~cm}^{3} \times 100}{\mathrm{~g} \text { cheese } \times \% \mathrm{DM}}
\end{gathered}
$$

\subsubsection{Validation}

Validation protocol has been accomplished in terms of limit of detection (LoD), limit of quantification (LoQ), linearity and precision. Both LoD and LoQ have been calculated according to Currie [33]. A linear calibration plot obtained by standard solutions quite close to the expected LoQ value was built and the blank signal was measured ten times. Hence, the LoD was calculated as follows:

$$
\operatorname{LoD}=3.3 \frac{\sigma}{\mathrm{a}}
$$

where $\sigma$ is the standard deviation of the ten measurements of the blank signal and a is the slope of the calibration plot measured at enzymatic activities only slightly higher than LoQ. Linearity has been evaluated in terms of both correlation coefficient $\left(R^{2}\right)$ and residues analysis, whereas precision was measured in terms of both repeatability and intermediate precision. Finally, the acceptability of precision data was tested according to Horwitz's theory [34]. 


\section{Results and Discussion}

\subsection{Method Assessment}

\section{General Remarks}

Previous literature $[17,21,22]$ reported the RP-HPLC measurement of activity of the FSC in milk of different origin. The methods were based on the quantification of pNP obtained by the enzyme-mediated hydrolysis, at $\mathrm{pH}=5.5$ and $37^{\circ} \mathrm{C}$, of a precursor intentionally added, i.e., the pNPFP. The unit of the enzyme activity $(\mathrm{U})$ is here assumed as the quantity of enzyme able to release $1 \mathrm{nmol}$ of pNP per hour. In a previous work of this research group, two different methods for the determination of the activity of the FSC in sheep milk were assessed, validated and tested with a large number of samples [17]. The enzymatic variability was also investigated as a function of both chemical and technological parameters as $\mathrm{pH}$, lipids content, interval of thermal inactivation, animals' diet, and lactation period [19]. Between both methods proposed by Piga et al. [17], the HPLC method is characterized, in comparison to the UV one, by a lower limit of detection, a greater operative simplicity and a better automatization level. For this reason, in the present work, the RP-HPLC method was chosen to develop a new analytical tool to measure the activity of the FSC enzyme in cheese.

\subsection{Validation}

Table 4 reports the parameters considered in the validation protocol.

Table 4. Validation parameters for the determination of $\alpha$-l-fucosidase activity in Fiore Sardo cheese.

\begin{tabular}{|c|c|c|c|c|c|c|}
\hline \multirow[t]{2}{*}{$\begin{array}{c}\mathrm{LoD}^{\mathrm{a}} \\
\left(\mathrm{Uh}^{-1} \mathrm{~g}_{\mathrm{DM}}{ }^{-1}\right)\end{array}$} & \multirow[t]{2}{*}{$\begin{array}{c}\text { LoQ } \\
\left(\mathrm{Uh}^{-1} \mathrm{~g}_{\mathrm{DM}}{ }^{-1}\right)\end{array}$} & \multirow{2}{*}{$\begin{array}{c}\text { Linearity } \\
\text { Concentration range } \\
\left(\mathrm{Uh}^{-1} \mathrm{~g}_{\mathrm{DM}}{ }^{-1}\right): 3.8 \div 189.3\end{array}$} & \multicolumn{2}{|c|}{ Repeatability $^{b}$} & \multicolumn{2}{|c|}{ Intermediate Precision $^{c}$} \\
\hline & & & $\begin{array}{l}\text { Sample, month } \\
\left(\mathrm{Uh}^{-1} \mathrm{~g}_{\mathrm{DM}}{ }^{-1}\right)\end{array}$ & $\mathrm{CV}$ & $\begin{array}{l}\text { Sample, month } \\
\left(\mathrm{Uh}^{-1} \mathrm{~g}_{\mathrm{DM}}{ }^{-1}\right)\end{array}$ & $\mathrm{CV}$ \\
\hline \multirow[t]{2}{*}{1.1} & 3.3 & $\begin{array}{l}\mathrm{Y}=\left(\mathrm{a} \pm \mathrm{s}_{\mathrm{a}}\right) \mathrm{X}+\left(\mathrm{b} \pm \mathrm{s}_{\mathrm{b}}\right) \\
\mathrm{a}=0.1321 ; \mathrm{s}_{\mathrm{a}}=0.0004\end{array}$ & RC, February & 2.9 & RC, February & 3.8 \\
\hline & & $\begin{array}{c}\mathrm{b}=-0.18 ; \mathrm{s}_{\mathrm{b}}=0.15 \\
\mathrm{R}^{2}=0.9999\end{array}$ & TC, February & 2.7 & TC, February & 4.1 \\
\hline
\end{tabular}

s, standard deviation; $\mathrm{R}^{2}$, correlation coefficient; ${ }^{a}$ the LoD value is measured according to [33], considering in the calculation an average amount of dry matter in the cheese of $70 \%$; ${ }^{b}$ evaluated by analyzing the same sample ten times within the same analytical session; ${ }^{c}$ evaluated by analyzing five times the same sample by two different technicians in two different analytical sessions within one month. Within this period, the sample was stored at $-24{ }^{\circ} \mathrm{C}$ in order to prevent any loss of enzymatic activity.

Figure 2 reports the linear calibration plot measured in the range of enzymatic activity between 3.8 and $38 \mathrm{U} \mathrm{h}^{-1} \cdot \mathrm{gDM}^{-1}$ and, in the inset, the overlaps of the chromatographic peaks of pNP obtained in the same range of enzymatic activity.

A good LoD value of $1.1 \mathrm{Uh}^{-1} \cdot \mathrm{gDM}^{-1}$ (i.e., $0.15 \mathrm{Uh}^{-1} \mathrm{~cm}^{-3}$ ) has been obtained in this way. This amount is at least one order of magnitude lower than those previously calculated by Mckellar et al., [20] and De Noni, [21], for cow milk, and by Piga et al., [17] for sheep milk. Linearity has been evaluated within the operative interval of the activities currently measured in this study, ranging between 3.8 and $189.3 \mathrm{Uh}^{-1} \cdot \mathrm{g}_{\mathrm{DM}}{ }^{-1}$. An excellent correlation coefficient $\left(\mathrm{R}^{2}\right)$ has been measured in this interval. In addition, the value of $b$ in the linear regressions appears always to be not significantly different from zero (criteria: two-tailed t test, $p=0.95$ ). Furthermore, any "hidden" deviation from linearity was excluded based on the graphical evaluation of the residuals of the regression line.

Precision was always measured in terms of percent coefficient of variation (CV). Both RC and TC representative samples of Fiore Sardo have been chosen to evaluate these parameters. Repeatability was always less than 3\%, whereas the worst value measured for the intermediate precision was $4.1 \%$. These values are better than those previously obtained for bovine milk [20,21] (6.0\% in both cases) and, for sheep milk [17] (4.5\%). The application of Horwitz's theory [34] to precision data supported their acceptability in relation to the level of concentration of the analyte. 
The absence of any certified reference material, as well as of any known independent analytical method aimed to measure the enzymatic activity of $\alpha$-l-fucosidase in cheeses have prevented us from adopting one of these reliable approaches to evaluate the trueness of the method. The last possibility to accomplish the measurement of trueness of the proposed method, but also the least reliable among all, was the attempt to evaluate the recoveries of analyte after multiple known additions in a real sample. Unfortunately, this approach was also unsuccessful because of the very high dispersion of the obtained recoveries, likely due to differences between both the endogenous and the added enzyme action.

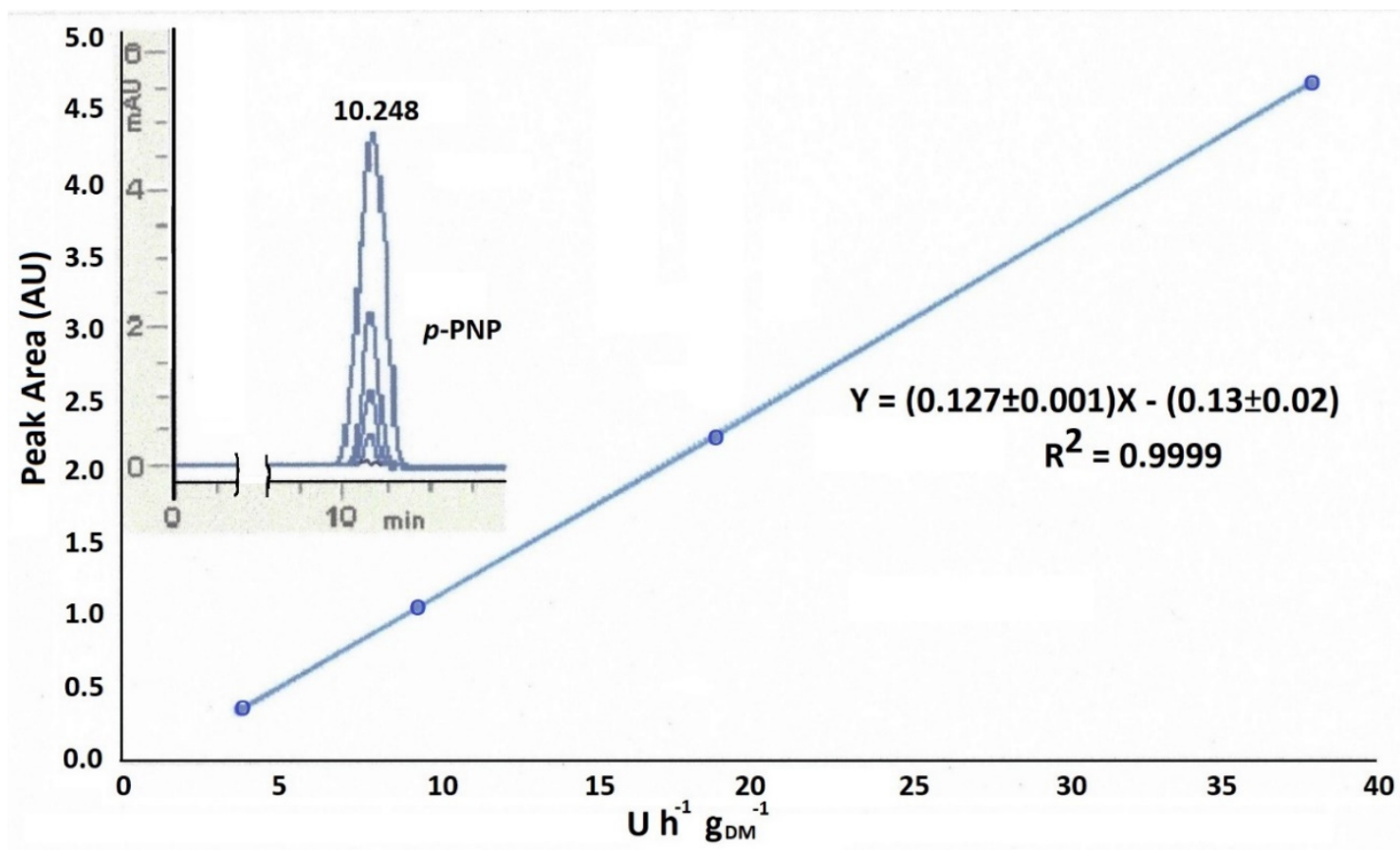

Figure 2. Linear calibration plot of the pNP peaks within the range of enzymatic activity between 3.8 and $38 \mathrm{U} \mathrm{h}^{-1} \cdot \mathrm{g}_{\mathrm{DM}}{ }^{-1}$. The inset shows the overlaps of the relevant chromatographic peaks and the blank signal within the same interval of enzymatic activity.

\subsection{Evaluation of FSC Activity in Fiore Sardo Obtained from Raw and Thermized Milk}

The proposed method has been tested analyzing Fiore Sardo RC and TC samples. Table 5 shows data related to the three experimental factors of variability taken into account for cheese milk: heat treatment (raw or thermized), lactation periods (December, February, April and May, respectively) and ripening time (105 and 180 days, respectively).

Table 5. $\alpha$-l-Fucosidase activity $\left(\mathrm{Uh}^{-1} \mathrm{~g}_{\mathrm{DM}}{ }^{-1}\right)$ in Fiore Sardo obtained from raw (RC) or thermized milk (TC) as a function of lactation periods and ripening time.

\begin{tabular}{|c|c|c|c|c|c|c|c|c|c|c|c|}
\hline \multirow[b]{3}{*}{$\begin{array}{l}\text { Treatment of } \\
\text { the milk }\end{array}$} & \multicolumn{11}{|c|}{ Lactation Periods } \\
\hline & \multirow{2}{*}{$\begin{array}{c}\text { Ripening } \\
\text { Time } \\
\text { (Days) }\end{array}$} & \multicolumn{2}{|c|}{ December } & \multicolumn{2}{|c|}{ February } & \multicolumn{2}{|c|}{ April } & \multicolumn{2}{|c|}{ May } & \multirow[t]{2}{*}{$\mathbf{T}^{\mathbf{a}}$} & \multirow[t]{2}{*}{$\mathrm{P}^{\mathrm{b}}$} \\
\hline & & $\mathrm{RC}$ & TC & $\mathrm{RC}$ & $\mathrm{TC}$ & $\mathrm{RC}$ & $\mathrm{TC}$ & $\mathrm{RC}$ & TC & & \\
\hline $\begin{array}{c}\alpha-1- \\
\text { fucosidase }\end{array}$ & 105 & $12^{\mathrm{b}} \pm 1$ & $4.6^{\mathrm{d}} \pm 0.3$ & $29^{a} \pm 1$ & $8.8^{b c} \pm 0.3$ & $27.7^{\mathrm{a}} \pm 0.5$ & $5.8^{\mathrm{cd}} \pm 0.5$ & $30^{\mathrm{a}} \pm 1$ & $8^{c d} \pm 2$ & $* * *$ & $* * *$ \\
\hline $\begin{array}{c}\alpha-1- \\
\text { fucosidase }\end{array}$ & 180 & $9.1^{\mathrm{bc}} \pm 0.4$ & $6^{\mathrm{cd}} \pm 1$ & $30^{\mathrm{a}} \pm 3$ & $8^{\mathrm{cd}} \pm 1$ & $29^{a} \pm 2$ & $8.3^{b c} \pm 0.5$ & $30^{\mathrm{a}} \pm 1$ & $9^{b c} \pm 1$ & $* * *$ & $* * *$ \\
\hline$\% \mathrm{AE}_{\text {res }}$ & 180 & \multicolumn{2}{|c|}{$70^{\mathrm{a}} \pm 10$} & \multicolumn{2}{|c|}{$27^{\mathrm{b}} \pm 4$} & \multicolumn{2}{|c|}{$28^{\mathrm{b}} \pm 3$} & \multicolumn{2}{|c|}{$29^{b} \pm 4$} & & $* * *$ \\
\hline
\end{tabular}

$\% \mathrm{EA}_{\text {res }}=(\mathrm{CT}$ activity $/ \mathrm{CR}$ activity $) \times 100{ }^{\mathrm{a}} \mathrm{T}$, effect of thermal treatment; ${ }^{\mathrm{b}} \mathrm{P}$, effect of month of production; ns, not significant; ${ }^{* * *}, p<0.001$. Different letters on the same line refer to significantly different average values. 
The trend of the data reported for Fiore Sardo at 105 and 180 days of ripening and produced in different lactation periods is somewhat different with those previously measured in raw sheep milk [18]. While the milk shows an overall increasing trend of the enzyme activity throughout the lactation period, this parameter seems to be roughly constant in the Fiore Sardo from raw milk (RC) produced from February to May, whereas significantly lower values were measured in the RC cheese produced in December. However, the different frequencies of the measurements in the two experiments could be responsible for the differences observed among the relevant trends. The low values of enzymatic activity (i.e., roughly one third of the average values measured in the February-May period) measured in the cheese produced in December might be explained on the basis of the typical sheep breeding adopted in Sardinia, which provides one birth per year, usually synchronized in November. Hence, all sheep in the herd follow the same lactation cycle and, contrary to what happens in cow herds, it is normal that the composition of the bulk of sheep milk significantly varies during the lactation cycle [18]. More specifically, the low enzymatic activity in the early stage of lactation could be attributed to the differences between early-stage milk, secreted by sheep in the colostrum lactation phase, and the milk produced by sheep in full lactation season.

As expected by literature findings [18], the thermization of sheep milk caused a sharp decrease in the FSC activity. In fact, this was significantly lower in Fiore Sardo from thermized milk (TC) than raw milk (RC) (Table 5). In addition, the seasonal behavior previously described for the Fiore Sardo made by raw milk is confirmed also for cheeses obtained from thermized milk. Data show that the average percent residual activity of FSC (\%EA $\left.\mathrm{E}_{\text {res }}\right)$ in cheeses from milk produced in December and measured after 105 and 180 days of ripening was 39\% and 70\%, respectively, whereas the same parameter, measured in cheeses produced in the remaining period, ranged between 21 and $30 \%$.

Since the unicity of these data prevents a comparison with those obtained in others cheeses, a tentative comparison has been made with the loss of the enzyme activity shown by the thermized milk with respect to raw milk as a function of the lactation period. Hence, data obtained in this study seem to be congruent with those observed for cow milk [20,21] (30\% and $27 \%$, respectively) and by Piga et al., [18] for sheep milk.

The absence of any meaningful difference among data reported in Table 5 for the same cheese substantiates the negligible effect of the ripening of Fiore Sardo towards the FSC activity. Since the PDO specifications of Fiore Sardo impose a minimum ripening time (105 days) before marketing, the invariance of the FSC activity as a function of the ripening time represent valuable information that supports the reliability of this enzyme as a tool to reveal possible frauds related to an illicit use of heat-treatment of milk in this method of cheese production.

\section{Conclusions}

For the first time a RP-HPLC method devoted to the evaluation of FSC activity in raw milk cheese has been developed, validated and applied to a valuable PDO cheese from Sardinia (Italy): the Fiore Sardo. The method has been first developed on the bases of the deep experience owned by this research group on sheep milk and its dairy products, and then validated for its sensitivity, linearity and precision. A low LoD, a good linearity within the experimental concentration range, and a great precision are the most meaningful results of the method proposed. The validated method has been tested in Fiore Sardo cheese samples produced in four laboratory batches from raw (or thermized) sheep milk, in order to ascertain if it could be eligible to reveal frauds related to the use of heat-processed sheep milk during the cheese-making. The results obtained in this study can be summarized as follows: (1) the FSC activity in Fiore Sardo produced with raw milk from the beginning of the sheep lactation cycle (i.e., December samples) is roughly one third of the activity measured in cheeses produced in the February-May period; (2) the FSC activity measured in Fiore Sardo produced by thermized sheep milk is always largely below the amounts found in the same cheese produced by raw milk; (3) the ripening of the Fiore Sardo has no meaningful effect on the activity of the $\alpha$-l-fucosidase. Hence, at 
the current stage of the research, the method proposed seems to be a promising tool to reveal frauds related to the use of thermized milk in Fiore Sardo cheese and, likely, also in other raw milk cheeses. However, due the extreme geographical variability (mainly ascribed to differences in both the nature and the altitude of the pastures) as well as its large technological variability (i.e., the nature and the technique of preparation of the lamb paste rennet, the water activity, the $\mathrm{pH}$, the $\mathrm{NaCl}$ concentration, the time and the temperature of ripening, as well as the existence of many "tricks of the trade" that each cheesemaker usually adopts, all not strictly described in the PDO specifications of Fiore Sardo), further studies will be planned in order to check the overall reliability of the method here described, as well as to assess a FTIR prediction method aimed to discriminate among cheeses made from raw or thermized milk.

Author Contributions: Conceptualization, M.A. and G.P.; methodology, M.A.; validation, A.S.D., L.P., M.A. and G.S.; investigation, A.S.D. and L.P.; data curation, A.P. and A.M.; writing-original draft preparation, A.S.D. and M.A.; writing-review and editing, A.S.D., M.A.,A.P. and G.S.; visualization, A.M.; supervision, M.A., A.P., G.P. and G.S.; project administration, A.P.; funding acquisition, A.P. All authors have read and agreed to the published version of the manuscript.

Funding: This work was supported by Regione Autonoma della Sardegna, Italy (Legge Regionale n. 15 del 17.11.2010).

Acknowledgments: The technical staff of both the Chemistry and Technology sectors of Agris Sardegna is gratefully acknowledged.

Conflicts of Interest: The authors declare no conflict of interest.

\section{References}

1. Italian Republic. DPR 14 Gennaio 1997, n. 54 Regolamento Recante Attuazione Delle Direttive 92/46 e 92/47/CEE in Materia di Produzione e Immissione Sul Mrcato di Latte e di Prodotti a Base di Latte. (Gazzetta Ufficiale Serie Generale n.59 del 12-03-1997-Suppl. Ordinario n. 54). Available online: https:/www.gazzettaufficiale.it/atto/serie_generale/caricaDettaglioAtto/originario? atto.dataPubblicazioneGazzetta=1997-03-12\&atto.codiceRedazionale=097G0082\&elenco30giorni=false (accessed on 8 June 2020). (In Italian)

2. Council Directive 92/46/EEC of 16 June 1992. Health Rules for the Production and Placing on the Market of Raw Milk, Heat-Treated Milk and Milk-Based Products. Off. Journal L 268, 14/09/1992. pp. 1-32. Available online: https://eur-lex.europa.eu/legal-content/EN/TXT/PDF/?uri=CELEX:31992L0046\&from=en (accessed on 8 June 2020).

3. Milk and Milk Products_Determination of Alkaline Phosphatase Activity_Part 1: Fluorimetric Method for Milk and Milk-Based Drinks; ISO 11816-1:2013; IDF: Brussels, Belgium, 2013; Volume 155-1.

4. Milk and Milk Products-Determination of Alkaline Phosphatase Activity-Part 2: Fluorometric Method for Cheese; ISO 11816-2:2003; IDF: Brussels, Belgium, 2003; Volume 155-2.

5. Milk-Determination of the Lactoperoxidase Activity_Photometric Method (Reference Method); ISO/TS 17193:2011; IDF: Brussels, Belgium, 2011; Volume 208.

6. McKellar, R.C.; Emmons, D.B.; Farber, J. Gamma-Glutamyl transpeptidase in milk and butter as an indicator of heat treatment. Int. Dairy J. 1991, 1, 241-251. [CrossRef]

7. Patel, S.S.; Wilbey, R.A. Thermal inactivation of $\gamma$-Glutamyltranspeptidase and enterococcus faecium in milk-based systems. J. Dairy Res. 1994, 61, 263-270. [CrossRef] [PubMed]

8. Pellegrino, L.; Resmini, P.; Luf, W. Assessment (indices) of heat treatment of milk. In Heat-Induced Changes in Milk, 2nd ed.; Fox, P.F., Ed.; Special Issue 9501; International Dairy Federation: Brussels, Belgium, 1995; pp. 409-453.

9. Fox, P.F.; Mcsweeney, P.L.H. Dairy Chemistry and Biochemistry; Blackie Academic \& Professional: London, UK, 1998.

10. Anjos, F.D.; Machado, A.; Ferro, C.; Otto, F.; Bogin, E. Gamma-Glutamyltransferase as a marker for the pasteurization of raw milk. J. Food Prot. 1998, 61, 1057-1059. [CrossRef] [PubMed] 
11. Blel, M.; Guingamp, M.-F.; Gaillard, J.-L.; Humbert, G. Studies on the thermal sensitivity of $\gamma$-Glutamyl transpeptidase measured with a modified test procedure and compared with that of alkaline phosphatase and lactoperoxidase in Milk. Le Lait 2002, 82, 555-566. [CrossRef]

12. Lorenzen, P.C.; Martin, D.; Clawin-Rädecker, I.; Barth, K.; Knappstein, K. Activities of alkaline phosphatase, $\gamma$-Glutamyltransferase and lactoperoxidase in cow, sheep and goat's milk in relation to heat treatment. Small Rumin. Res. 2010, 89, 18-23. [CrossRef]

13. Chávarri, F.; Santisteban, A.; Virto, M.; de Renobales, M. Alkaline phosphatase, acid phosphatase, lactoperoxidase, and lipoprotein lipase activities in industrial ewe's milk and cheese. J. Agric. Food Chem. 1998, 46, 2926-2932. [CrossRef]

14. Scintu, M.F.; Daga, E.; Ledda, A. Evaluation of spectrophotometric and fluorometric methods for alkaline phosphatase activity determination in ewe's milk. J. Food Prot. 2000, 63, 1258-1261. [CrossRef]

15. Barbosa, M. Interest in controlling alkaline phosphatase activity in sheep and goat milks. In The Future of the Sheep, Goat Dairy Sector; IDF, Ed.; IDF: Brussels, Belgium, 2005; pp. 117-121.

16. Piga, C.; Urgeghe, P.P.; Piredda, G.; Scintu, M.F.; Sanna, G. Assessment and validation of methods for the determination of $\gamma$-Glutamyltransferase activity in sheep milk. Food Chem. 2009, 115, 1519-1523. [CrossRef]

17. Piga, C.; Urgeghe, P.P.; Piredda, G.; Scintu, M.F.; Sanna, G. Analytical methods for the evaluation of $\alpha$-L-Fucosidase activity in sheep milk. Food Anal. Methods 2008, 3, 17-21. [CrossRef]

18. Piga, C.; Urgeghe, P.P.; Piredda, G.; Scintu, M.F.; Di Salvo, R.; Sanna, G. Thermal inactivation and variability of $\gamma$-Glutamyltransferase and $\alpha$-L-Fucosidase enzymatic activity in sheep milk. LWT Food Sci. Technol. 2013, 54, 152-156. [CrossRef]

19. Zehetner, G.; Bareuther, C.; Henle, T.; Klostermeyer, H.K. Inactivation of endogenous enzymes during heat treatment of milk. Neth. Milk Dairy J. 1996, 50, 215-226.

20. McKellar, R.C.; Piyasena, P. Predictive modelling of inactivation of bovine milk $\alpha$-L-Fucosidase in a high-temperature short-time pasteurizer. Int. Dairy J. 2000, 10, 1-6. [CrossRef]

21. De Noni, I. Study on the variability of fucosidase activity in bovine milk by means of HPLC. Int. Dairy J. 2006, 16, 9-17. [CrossRef]

22. Andrews, A.T.; Anderson, M.; Goodenough, P.W. A study of the heat stabilities of a number of indigenous milk enzymes. J. Dairy Res. 1987, 54, 237-246. [CrossRef]

23. Wiederschain, G.Y.; Newburg, D.S. Compartmentalization of fucosyltransferase and $\alpha$-L-Fucosidase in human milk. Biochem. Mol. Med. 1996, 58, 211-220. [CrossRef]

24. Addis, M.; Cabiddu, A.; Pinna, G.; Decandia, M.; Piredda, G.; Pirisi, A.; Molle, G. Milk and cheese fatty acid composition in sheep fed mediterranean forages with reference to conjugated linoleic acid Cis-9,trans-11. J. Dairy Sci. 2005, 88, 3443-3454. [CrossRef]

25. Urgeghe, P.P.; Piga, C.; Addis, M.; Di Salvo, R.; Piredda, G.; Scintu, M.F.; Wolf, I.V.; Sanna, G. SPME/GC-MS characterization of the volatile fraction of an Italian PDO sheep cheese to prevalent lypolitic ripening: The case of fiore sardo. Food Anal. Methods 2011, 5, 723-730. [CrossRef]

26. Zazzu, C.; Addis, M.; Caredda, M.; Scintu, M.F.; Piredda, G.; Sanna, G. Biogenic amines in traditional fiore Sardo PDO sheep cheese: Assessment, validation and application of an RP-HPLC-DAD-UV method. Separations 2019, 6, 11. [CrossRef]

27. Caboni, P.; Maxia, D.; Scano, P.; Addis, M.; Dedola, A.; Pes, M.; Murgia, A.; Casula, M.; Profumo, A.; Pirisi, A. A gas chromatography-mass spectrometry untargeted metabolomics approach to discriminate fiore sardo cheese produced from raw or thermized ovine milk. J. Dairy Sci. 2019, 102, 5005-5018. [CrossRef]

28. Milk, Cream and Evaporated Milk—Determination of Total Solids Content (Reference Method); ISO 6731:2010; IDF: Brussels, Belgium, 2010; Volume 21.

29. Cheese and Processed Cheese-Determination of the Total Solids Content (Reference Method); ISO 5534:2004; IDF: Brussels, Belgium, 2004; Volume 4.

30. Milk and Milk Products-Determination of Nitrogen Content-Part 1: Kjeldahl Principle and Crude Protein Calculation; ISO 8968-1:2014; IDF: Brussels, Belgium, 2014; Volume 20-1.

31. Cheese and Processed Cheese Products_Determination of Chloride Content_Potentiometric Titration Method; ISO 5943:2006; IDF: Brussels, Belgium, 2006; Volume 88.

32. Soxhlet, F. Die gewichtsanalytische Bestimmung des Milchfettes. Dinglers Polytech. J. 1879, 232, 461-465. 
33. Currie, L.A. Nomenclature in evaluation of analytical methods including detection and quantification capabilities. Anal. Chim. Acta 1999, 391, 105-126. [CrossRef]

34. Horwitz, W. Evaluation of analytical methods used for regulation of foods and drugs. Anal. Chem. 1982, 54, 67-76. [CrossRef] 